\title{
Teaching NeuroImages: The zigzag edging sign of adult-onset neuronal intranuclear inclusion disease
}

Neurology ${ }^{\circledR}$ 2019;93:415. doi:10.1212/WNL.0000000000007922

In the article "Teaching NeuroImages: The zigzag edging sign of adult-onset neuronal intranuclear inclusion disease" by Chen et al., ${ }^{1}$ the second-to-last sentence in the first paragraph should read "FMR1 CGG permutation was not present." The publisher regrets the error.

\section{Reference}

1. Chen L, Chen A, Lei S, et al. Teaching NeuroImages: The zigzag edging sign of adult-onset neuronal intranuclear inclusion disease. Neurology 2019;92:e2295-e2296.

\section{Opinion and Special Articles: Self-management in epilepsy}

Web-based seizure tracking applications

Neurology ${ }^{\circledR}$ 2019;93:415. doi:10.1212/WNL.0000000000007480

In the article "Opinion and Special Articles: Self-management in epilepsy: Web-based seizure tracking applications" by Casassa et al., ${ }^{1}$ first published online November 19, 2018, NIH Grant T32NS048005 should have been listed as a funding source. The authors regret the error.

\section{Reference}

1. Casassa C, Rathbun Levit E, Goldenholz DM. Opinion and Special Articles: Self-management in epilepsy: web-based seizure tracking applications. Neurology 2018;91:e2027-e2030.

\section{Cost of illness in Charcot-Marie-Tooth neuropathy}

Results from Germany

Neurology ${ }^{\circledR}$ 2019;93:415. doi:10.1212/WNL.0000000000007916

In the article "Cost of illness in Charcot-Marie-Tooth neuropathy: Results from Germany" by Schorling et al., ${ }^{1}$ first published online March 27, 2019, the published-online-ahead-of-print version should have presented figures in USD rather than euros. They are presented correctly in the April 23 issue. The editorial office regrets the error.

\section{Reference}

1. Schorling E, Thiele S, Gumbert L, et al. Cost of illness in Charcot-Marie-Tooth neuropathy: results from Germany. Neurology 2019;92: e2027-e2037.

\section{Comprehensive systematic review summary: Treatment of tics in people with Tourette syndrome and chronic tic disorders Neurology ${ }^{\circledR}$ 2019;93:415. doi:10.1212/WNL.0000000000007918}

In the article "Comprehensive systematic review summary: Treatment of tics in people with Tourette syndrome and chronic tic disorders" by Pringsheim et al., ${ }^{1}$ first published online May 6, 2019, the data supplement link in the first paragraph should have been: links.lww.com/ WNL/A882. The authors regret the error.

\section{Reference}

1. Pringsheim T, Holler-Managan Y, Okun MS, et al. Comprehensive systematic review summary: Treatment of tics in people with Tourette syndrome and chronic tic disorders. Neurology 2019; 92:907-915. 


\title{
Neurology
}

\section{Opinion and Special Articles: Self-management in epilepsy: Web-based seizure tracking applications \\ Neurology 2019;93;415 \\ DOI 10.1212/WNL.0000000000007480}

This information is current as of August 26, 2019

\author{
Updated Information \& \\ Services \\ including high resolution figures, can be found at: \\ http://n.neurology.org/content/93/9/415.2.full \\ References \\ This article cites 1 articles, 1 of which you can access for free at: \\ http://n.neurology.org/content/93/9/415.2.full\#ref-list-1 \\ Permissions \& Licensing \\ Information about reproducing this article in parts (figures,tables) or in \\ its entirety can be found online at: \\ http://www.neurology.org/about/about_the_journal\#permissions \\ Reprints \\ Information about ordering reprints can be found online: \\ http://n.neurology.org/subscribers/advertise
}

Neurology ${ }^{\circledR}$ is the official journal of the American Academy of Neurology. Published continuously since 1951 , it is now a weekly with 48 issues per year. Copyright @ 2019 American Academy of Neurology. All rights reserved. Print ISSN: 0028-3878. Online ISSN: 1526-632X.

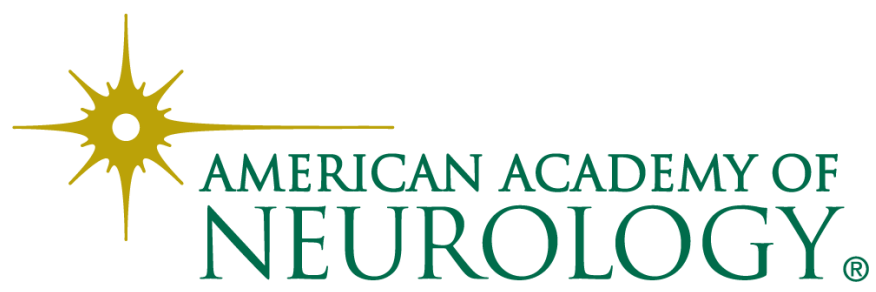

